\title{
Generational Diversity: Implications For Healthcare Leaders
}

\author{
Valerie Dong Olson, Seton Hall University, USA
}

\begin{abstract}
Amid the multifaceted complexities of the current health care environment and today's workforce, intergenerational issues created uncharted territory for health care leaders. As a result, healthcare institutions reveal organizational cultures of conflict due to the generational differences in core values and work related issues. In addition, driving forces also consist of the economic, political and social influences of the generational period. It is essential that healthcare leaders understand and take proactive strategies to develop synergism to span the generational gaps as integral components of healthcare organizational culture.
\end{abstract}

Keywords: Generational diversity, healthcare leaders, synergism

\section{INTRODUCTION}

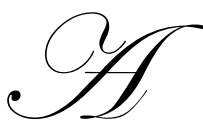

mid the multifaceted complexities of the current healthcare environment and today's workforce, intergenerational issues create uncharted territory for healthcare leaders (Cabot, 2006). Healthcare institutions have developed into organizational cultures of conflict, based upon the varied core values and preferences of the intergenerational work force. Furthermore, some believe that the differences may stem from the generational period's economic, political and social events (Dittman, 2005). Consequently, it is important for healthcare leaders to be astute of the existing diversity of the generational groups to move an organization towards its mission and vision. In order to address the intergenerational issues and lead an institution to excellence, healthcare leaders require the essential knowledge and training of generational diversity to create synergism within the organizational culture.

\section{THE GENERATIONS IN THE WORKPLACE}

The major generational groups consist of Matures, Baby Boomers, Generation X, and Millenials (Diversity Leadership Guide; Noble, Schewe \& Kuhr, 2004).

The Matures (also coined Veterans), who were born from 1922 to 1945 and are 63 and older, consist of the "traditionalists" and were raised with the influence of World War II. They demonstrate the "American values" of hard work, personal sacrifice, law and order, conformity, and delayed gratification.

The Baby Boomers were born between 1946 and 1964, and currently are 44 to 62 years old. They are a large group of people who are optimistic and seek opportunity. This "Me Generation" values personal gratification, the work life, a team approach, and involvement.

Born between 1965 and 1978, the Generation Xers ranges in age from 25 to 45 years old. This group values self-reliance, informality, and technoliteracy, and they are more skeptical; they are not intimidated by authority, rules, and the chain of command.

The Millenials (also referred to as Generation Y), born between 1979 and 2000, are younger than 29, and are the most affluent, highly educated group. They demonstrate positive social habits and teamwork, value diversity, and tend to follow rules. The brief overview of the various generational characteristics profiles a highly diverse and unique workforce. There are distinct leadership and work styles, which create an organizational culture of differences. (Refer to Table 1.) 


\section{GENERATIONAL DIFFERENCES: PROS AND CONS}

Problems that arise from generational differences impede effective and efficient collaboration between the health care leaders and the work force (Stanley, 2007). Generational diversity, such as workforce differences in attitudes, values and beliefs, work ethics and habits, and expectations, has been challenging for health care leaders (Sherman, 2006). The complex matrix of generational characteristics provides the evidence supporting a distinction between interaction and communication. (Refer to Table 1.) Moreover, health care team members are regularly scrutinized and evaluated as to how effectively they work in a team. The exemplary employee in the health care setting is required to communicate and adapt quickly to the dynamics of the group and contribute to the charge or program. The dilemma of generational differences influences the process.

In the healthcare setting, the goal is to unleash the potential of each team member and foster the harmony throughout all levels and departments in the healthcare institution to achieve the facility's mission and vision. However, the team's communication may not be optimal for such a goal, thwarting the essential synergism, where the sum is greater than the parts. Synergism consists of the integration of the unique characteristics embodied in generational diversity to span the generation gaps (Raines, 2002).

Table 1: Differences of Four Generations

\begin{tabular}{|c|c|c|c|c|}
\hline & Mature (Veterans) & Baby Boomers & Generation X & Millenials (Gen Y) \\
\hline Birth Years & $1922-1945$ & 1946-1964 & $1965-1978$ & $1979-2000$ \\
\hline$\overline{\text { Age Range }}$ & 63-86 years old & 44-62 years old & $30-43$ years old & 8-29 years old \\
\hline Driving Forces & $\begin{array}{l}\text { Great Depression } \\
\text { World War II } \\
\text { Education with rules and } \\
\text { respect of authority } \\
\text { Husband provider and wife } \\
\text { managed home and raised } \\
\text { children } \\
\text { Responsible citizens }\end{array}$ & $\begin{array}{l}\text { Economic prosperity } \\
\text { Consumerism } \\
\text { Post-World War II } \\
\text { Husband and wife } \\
\text { worked outside home } \\
\text { and shared } \\
\text { responsibility for } \\
\text { childcare and household }\end{array}$ & $\begin{array}{l}\text { Declining economy and } \\
\text { saw parents being laid } \\
\text { off from jobs held for } \\
\text { years } \\
\text { Viet Nam War } \\
\text { Encouraged to find a job } \\
\text { they enjoyed }\end{array}$ & $\begin{array}{l}\text { Often children of Baby } \\
\text { Boomers } \\
\text { Largest group with more } \\
\text { than } 30 \text { million people } \\
\text { than Gen X } \\
\text { Independent at an early } \\
\text { age as they grew up in } \\
\text { dual-working } \\
\text { households }\end{array}$ \\
\hline $\begin{array}{l}\text { Workforce } \\
\text { Attitudes }\end{array}$ & $\begin{array}{l}\text { Seniority } \\
\text { Respect elders and people } \\
\text { in authority } \\
\text { Motivated by security }\end{array}$ & $\begin{array}{l}\text { Commitment, } \\
\text { dedication, hard work \& } \\
\text { loyalty } \\
\text { Motivated by money \& } \\
\text { consumerism } \\
\text { Career women in the } \\
\text { workforce }\end{array}$ & $\begin{array}{l}\text { Loyalty thing of past, } \\
\text { may be loyal to manager } \\
\text { and not company } \\
40 \text { hour week a thing of } \\
\text { the past } \\
\text { Productivity measured } \\
\text { by success and output } \\
\text { (not by number of hours } \\
\text { in the office) } \\
\text { Motivated by time off }\end{array}$ & $\begin{array}{l}\text { High energy level } \\
\text { Easily bored and } \\
\text { minimal loyalty } \\
\text { Culturally Skilled } \\
\text { Globally oriented } \\
\text { Requires fast results } \\
\text { Motivated by time off }\end{array}$ \\
\hline Values/Beliefs & $\begin{array}{l}\text { Family \& community } \\
\text { Money is livelihood }\end{array}$ & $\begin{array}{l}\text { Competitive } \\
\text { Success } \\
\text { Money is status symbol }\end{array}$ & $\begin{array}{l}\text { Time } \\
\text { Function over form } \\
\text { Money is a means to an } \\
\text { end }\end{array}$ & $\begin{array}{l}\text { Individuality } \\
\text { Entrepreneurial } \\
\text { Work to benefit the } \\
\text { larger society } \\
\text { Money is today's payoff }\end{array}$ \\
\hline $\begin{array}{l}\text { Work Ethics \& } \\
\text { Habits }\end{array}$ & $\begin{array}{l}\text { Quality } \\
\text { Dedicated } \\
\text { Highest company loyalty }\end{array}$ & $\begin{array}{l}\text { Long Hours } \\
\text { Driven } \\
\text { High company loyalty }\end{array}$ & $\begin{array}{l}\text { "Me" focus } \\
\text { Productivity } \\
\text { Balanced } \\
\text { Low company loyalty }\end{array}$ & $\begin{array}{l}\text { "Me" focus } \\
\text { Multi-tasker } \\
\text { Contribution } \\
\text { Ambitious } \\
\text { Low company loyalty }\end{array}$ \\
\hline Expectations & Work hard to live & Make a good living & $\begin{array}{l}\text { Work at a facility you } \\
\text { like }\end{array}$ & $\begin{array}{l}\text { Work at a facility you } \\
\text { like to earn income } \\
\text { today }\end{array}$ \\
\hline
\end{tabular}

(Adapted from: Diversity Leadership Guide (January/February 2006). Retrieved on 5/28/08 from

www.grc.nasa.gov/WWW/diversity/LeaderhsipGuideJanFeb06.pdf 
The differences of the generations also influence the recruitment and retention of the healthcare team members, which compounds the dilemma. Enhanced job satisfaction is important for productivity and retention, and reduces the turnover of healthcare team members. As a result, continuity of healthcare and team membership, and significant reduction of related monetary expenses are achieved.

Due to the complexities, health care team members are hesitant to assume and/or fulfill health care leadership roles, as well as to build for leadership succession. Succession planning is essential for the regeneration of an institution's leadership, more importantly, for the development of strong leadership teams addressing strategic planning and tasks (Leibman, Bruer \& Maki, 1996). With the understanding of generational differences and its implications, the planning of the healthcare administration needs to be more flexible and dynamic to develop strong leadership. (Refer to Table 2.)

Table 2: Relating to Generation Differences in the Workforce

\begin{tabular}{|c|c|c|c|c|}
\hline & Mature (Veterans) & Baby Boomers & Generation X & Millenials (Gen Y) \\
\hline Roles & $\begin{array}{l}\text { Address need for } \\
\text { respect and structure }\end{array}$ & $\begin{array}{l}\text { Emphasis on } \\
\text { dedication and loyalty } \\
\text { Company needs come } \\
\text { first }\end{array}$ & $\begin{array}{l}\text { Emphasis on time to } \\
\text { enjoy income }\end{array}$ & $\begin{array}{l}\text { Enjoy life and be } \\
\text { creative }\end{array}$ \\
\hline Instruction & $\begin{array}{l}\text { Provide clear } \\
\text { procedural instructions }\end{array}$ & $\begin{array}{l}\text { Technological } \\
\text { disadvantage due to } \\
\text { lack of exposure to } \\
\text { computer skills }\end{array}$ & $\begin{array}{l}\text { Skill and knowledge } \\
\text { acquisition important } \\
\text { Require continual } \\
\text { training to maintain } \\
\text { cutting-edge abilities }\end{array}$ & $\begin{array}{l}\text { Efforts to keep them } \\
\text { motivated and busy } \\
\text { Provide consistent } \\
\text { feedback and direction } \\
\text { Requires opportunities } \\
\text { to plan, build and } \\
\text { experience with new } \\
\text { methods }\end{array}$ \\
\hline Motivation & Emphasize quality & $\begin{array}{l}\text { Visible and tangible } \\
\text { rewards }\end{array}$ & $\begin{array}{l}\text { Needs work-life } \\
\text { balance }\end{array}$ & Live life and work \\
\hline $\begin{array}{l}\text { Technological } \\
\text { Influences }\end{array}$ & $\begin{array}{l}\text { Lack of exposure to } \\
\text { computers }\end{array}$ & $\begin{array}{l}\text { Widespread use of } \\
\text { computers and global } \\
\text { access }\end{array}$ & $\begin{array}{l}\text { Grew up in a world } \\
\text { with ever-changing } \\
\text { technology }\end{array}$ & $\begin{array}{l}\text { Grew up in } \\
\text { technologically } \\
\text { advanced society, } \\
\text { expanded to around the } \\
\text { world }\end{array}$ \\
\hline Leadership Style & Hierarchy & Consensus & Competence & Achievers \\
\hline
\end{tabular}

Although sparse, research in generational diversity indicates that healthcare professionals demonstrate limited knowledge in generational issues (Smola \& Sutton, 2002). Consequently, training in generational diversity in the workplace, specifically in healthcare institutions, is warranted.

\section{CULTIVATING SYNERGISM WITHIN THE HEALTHCARE CULTURE}

Synergism within the healthcare culture consists of a work environment that succeeds in the creation and implementation of flexible policies designed to meet the needs of the different generations, while embracing diversity. Knowledge of generational differences, typical communication, and relevant intergenerational issues in management and leadership are essential. Corresponding strategies are essential in order to enhance the health care leaders' ability to view and use generational diversity beneficially (Kupperschmidt, 2006). The manager views generational differences through their "managerial-colored" lenses. (Refer to Table 3.) In addition, the acquisition of knowledge and skills in reducing inter-generational conflict is important. 
Table 3: The Managerial Lense: Cultivating Generational Synergism

\begin{tabular}{|l|l|l|l|l|}
\hline \multicolumn{1}{|c|}{ Manager Role } & \multicolumn{1}{|c|}{ Mature } & \multicolumn{1}{c|}{ Baby Boomers } & \multicolumn{1}{c|}{ Generation X } & \multicolumn{1}{c|}{ Millenials } \\
\hline Attitudes & $\begin{array}{l}\text { Individuals may prefer } \\
\text { a consensus building, } \\
\text { versus a top-down } \\
\text { leader }\end{array}$ & $\begin{array}{l}\text { Ideas of respect may } \\
\text { not be shared by } \\
\text { supporting staff }\end{array}$ & $\begin{array}{l}\text { Onsite work hours may } \\
\text { be essential, even off } \\
\text { times to address client } \\
\text { needs }\end{array}$ & $\begin{array}{l}\text { Recognize that } \\
\text { creativity does not } \\
\text { always apply }\end{array}$ \\
\hline $\begin{array}{l}\text { Provision of } \\
\text { essential } \\
\text { information }\end{array}$ & $\begin{array}{l}\text { Understand the context } \\
\text { of the employee }\end{array}$ & $\begin{array}{l}\text { Understand one's } \\
\text { dedication and loyalty } \\
\text { may not be important }\end{array}$ & $\begin{array}{l}\text { Technology training } \\
\text { may be necessary as } \\
\text { individual comfort } \\
\text { levels differ }\end{array}$ & $\begin{array}{l}\text { Adapt instruction to } \\
\text { follow a logical step- } \\
\text { by-step sequences, } \\
\text { reducing "gray" areas }\end{array}$ \\
\hline Adaptability & $\begin{array}{l}\text { Apply "Put yourself in } \\
\text { their shoes" }\end{array}$ & $\begin{array}{l}\text { Do not confuse the } \\
\text { demonstrated } \\
\text { confidence with } \\
\text { arrogance }\end{array}$ & $\begin{array}{l}\text { Flexibility in the } \\
\text { workplace may not be } \\
\text { as effective }\end{array}$ & $\begin{array}{l}\text { Decision-making may } \\
\text { required increased time } \\
\text { and dialogue }\end{array}$ \\
\hline
\end{tabular}

In managing individuals of different generations, the emphasis is to recognize that the difference exists and not to expect individuals to change their way of thinking. Each generation is characterized through its own context, and managers and team members must learn to speak to that context for each individual (Diversity Leadership Guide). To foster skills in working with multiple generations in an ever-changing health care environment, open dialogue is essential in order to learn and to understand the generational differences. Strategies to initiate discussion may consist of questions to solicit individuals' perspectives of their own generation, and to share as to whether they agree or disagree with the related information and why. Questions may also be tailored to engage conversation on the positive and negative aspects of generational work ethics. To expand upon this theme, participants may be encouraged to describe their own successes and difficulties in working with other generations. The options provide a forum for open dialogue and self reflection of individuals' own understanding of generational diversity.

Raines (2002) addresses a variety of issues related to generational differences. To establish a broad approach to incorporate individuals from all generations, synergism is necessary. As the sum is greater than the parts, so the outcomes will span the generational gap. Focusing on tapping into the resources of a diverse workforce, Raines lists pointed questions that are thought provoking. She addresses the composition of the Board of Directors and if there is a Generation Xer or a Millennial. In regards to projections of those retiring, is a process established for building "bench strength"? In terms of activities to increase awareness, Raines suggests hosting an awareness event, watching movies illustrating generational differences, reviewing the benefits package to discern which generation group would most likely be attracted to each, developing an Employee Value Proposition--for each generation--which would list what is attractive about working for the healthcare institution, and having management create profiles of four ideal managers with one from each generation. The examples of experiential learning would cultivate generational synergism.

The non-monetary motivators designed for different generations may provide invaluable options to increase productivity and retention. For the Mature and Baby Boomer generations, the opportunity for assignments or part time work that requires analytical and strategic thinking affords the use of their talents. In addition, these generations have skills in gathering data and problem-solving, which are typically areas that are put aside for the urgent issues that need to be addressed. On the other hand, for the Gen X and Millenial generations, the provision of opportunities to work with the latest technology or to travel to satellite locations would be desirable. While the Millenials appreciate a supervisory style that consists of close supervision and feedback, the Gen X would be demotivated. The creation of experiences or programs that capitalize on the generations' strengths, while simultaneously aligning the outcomes with the healthcare facility's mission and vision, supports a win-win scenario (Schwarz, 2008).

Reframing the leaders' ability to build on the strengths and weaknesses of generations serves as a catalyst to achieve the desired organizational culture (Dittman, 2005). 


\section{CONCLUSION}

A brief overview of the generational groups, intergenerational issues, and inherent struggles of the health care work force is provided. Examples of practical strategies and corresponding action plans can be used as springboards for further creative thinking to span generational gap. Generational diversity promotes the continual challenge of thought processes, implementation of strategies and programs, and opportunities to provide exceptional healthcare. By understanding and embracing the generational diversity, health care leaders will be better equipped to fulfill their responsibilities and to foster the alignment of an institution's organizational culture with its mission and vision. The proactive approach, developed to search, value, respect and use generational diversity, enhances the communication, spans the gaps between generations, and promotes collaboration among healthcare leaders and team members.

\section{AUTHOR INFORMATION}

Valerie Dong Olson PT, PhD serves as Associate Faculty at Seton Hall University, New Jersey. She earned her BS in Physical Education from Southern Connecticut University, MS in Exercise Science from University of Massachusetts, and a BS in Health Sciences with a certificate in Physical Therapy from the University of Florida. Dr. Olson earned her PhD in Health Sciences from Seton Hall University. For over 25 years, Dr. Olson has been involved in administration, teaching, service, and research in higher education. Current research emphases are noted in teaching and learning, use of technology in education, and movement science.

\section{REFERENCES}

1. $\quad$ Cabot, L. (2006). Professional development for IT leaders. Education Quarterly. 1:54-56.

2. Dittman, M. (2005). Generational differences at work. Monitor on Psychology. Retrieved on 11/15/2007 http://www.apa.org/monitor/jun05/generational.html

3. Diversity Leadership Guide. Generations in the workplace. Retrieved on 5/10/08 http://www.grc.nasa.gov/WWW/diversity

4. Kupperschmidt, B. (2006). Addressing multigenerational conflict: Mutual respect and carefronting as strategy. Online Journal of Issues in Nursing, 11(2):4.

5. Leibman, M., Bruer, R., \& Maki, B. (1996). Succession management:The next generation of succession planning. Human Resource Planning, 19.

6. Noble, S., Schewe, C., \& Kuhr, M. (2004). Preferences in health care service and treatment: A generational perspective. Science Direct, 57(9):1033-1041.

7. Raines, C. (2002). Connecting Generations: The Sourcebook. Crisp Publication.

8. Sherman, R. (2006). Leading a multigenerational nursing workforce: Issues, challenges and strategies. Online Journal of Issues in Nursing, 11(2):3.

9. Smola, K. \& Sutton, C. (2002). Generational differences: revisiting generational work values for the new millennium. Journal of Organizational Behavior. 23(4):363-382.

10. Stanley, K. (2007). Age to age: Insight into managing a multigenerational staff. Journal of Medical Practice Management, 22(5):269-75.

11. Schwarz, R. Why managing generational differences is important. Retrieved on 5/10/08 http://www.marsvenusatwork.com/generations/htm 


\section{NOTES}

